\title{
Dez anos a serviço da construção do campo comunicação/educação
}

Maria Aparecida Baccega

Livre-docente aposentada da USP, Professora de pós-graduação da ECA-USP e da ESPM-SP,

Editora dos Cadernos de Pesquisa da ESPM-SP, Coordenadora adjunta do Núcleo de Pesquisa Comunicação e práticas de consumo - ESPM-SP.

E-mail:mabga@usp.br

Este é o $3^{\circ}$ número do Ano X da revista Comunicação \& Educação. Motivo de júbilo e de muitos agradecimentos.

Surgida em 1994, graças ao incentivo da Editora Moderna, na pessoa de seu editor Sérgio Couto, a qual acreditou no projeto, a revista nasceu da decisão de um conjunto de professores do Departamento de Comunicações e Artes da ECA, os quais, juntamente com suas pesquisas, com sua produção de conhecimento no campo da comunicação, sempre se preocuparam com a formação de alunos e docentes, de todos os níveis, além dos demais agentes de educação, para vivenciarem a contemporaneidade.

Da Editora Moderna passamos à Segmento; desta, para a Salesianas e, atualmente, Paulinas. Esta história é contada na mesa-redonda sobre os dez anos da revista, que está inclusa neste número.

Temos convicção de que começamos com uma revista sobre comunicação/ educação quando ainda não se falava nisso e, passados dez anos, vemos que contribuímos para a formação do campo e para uma maior clareza sobre esta questão.

A partir do próximo número, este artigo de Apresentação será feito pelos vários pesquisadores e docentes que compõem nossa Comissão de Publicação, em rodízio.

Aproveitando a comemoração dos dez anos, decidimos reapresentar a seguir nossa Carta de Princípios, tal qual publicada no número 1 desta revista, para que renovemos o compromisso e nos comprometamos a, cada vez mais, buscar a solidificação do campo comunicação/educação, colaborando, desse modo, de maneira decisiva, para a construção da cidadania. 
comunicação \& educação • Ano X • Número 3 • set/dez 2005

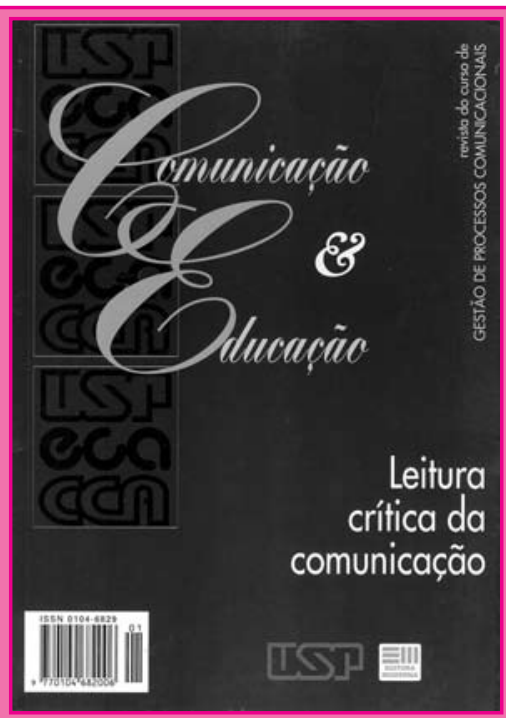

\section{DO MUNDO EDITADO À CONSTRUÇÃO DO MUNDO'}

Está nascendo a revista Comunicação \& Educação. Seu objetivo, como o próprio nome diz, é dialogar com o público sobre esse espaço, já construído, onde Educação e Comunicação se encontram. Trata-se de um espaço cuja ação está presente em cada sala de aula, em cada grupo de pessoas, em cada um de nós. Até mesmo nos nossos monólogos interiores, aquelas eternas conversas que cada um tem consigo próprio: para refletir sobre uma atitude, sobre um fato novo ("será que o Real [moeda brasileira que acabava de ser instituída] é mesmo vantajoso? até quando?"), para estruturar a seqüência do nosso dia ("vou dar aula, na saída apanho meu filho na escola, depois..."), para planejar o nosso mês (sempre mais longo que o salário) ou a própria vida.

E por que podemos afirmar que Comunicação/Educação é um espaço já construído?

Como diz Paulo Freire, nós vivemos no mundo e com o mundo. E que mundo é esse? É aquele que é trazido até o horizonte de nossa percepção, até o universo de nosso conhecimento. Afinal, não podemos estar "vendo" todos os acontecimentos, em todos os lugares. É preciso que "alguém" os relate para nós.

O mundo que nos é trazido, que conhecemos e a partir do qual refletimos é um mundo que nos chega EDITADO, ou seja, ele é redesenhado num trajeto que passa por centenas, às vezes milhares de filtros até que "apareça" no rádio, na televisão, no jornal. Ou na fala do vizinho e nas conversas dos alunos.

São esses filtros - instituições e pessoas - que selecionam o que vamos 1. BACCEGA, Maria Apare-
cida. Do mundo editado à construção do mundo. Comunicação \& Educação, São Paulo: CCA/ECA/USP/ Moderna, n. 1, p. 7-14, set./dez. 1994. 


\section{Dez anos a serviço da construção do campo comunicação/educação • \\ Maria Aparecida Baccega}

o mundo é editado e assim ele chega a todos nós; que sua edição obedece a interesses de diferentes tipos, sobretudo econômicos, e que, desse modo, acabamos por "ver" até nossa própria realidade do jeito que ela foi editada. Editar é, portanto, construir uma realidade outra, a partir de supressões ou acréscimos em um acontecimento. Ou, muitas vezes, apenas pelo destaque de uma parte do fato em detrimento de outra.

Editar é reconfigurar alguma coisa, dando-lhe novo significado, atendendo a determinado interesse, buscando um determinado objetivo, fazendo valer um determinado ponto de vista.

Até agora só falamos de um lado: o da produção dos programas (de rádio ou televisão), jornais, revistas, etc., o lado que edita o mundo para nós. Mas há o outro lado: o dos que "recebem" esses programas, os que lêem esses jornais e revistas. Esse outro lado somos nós, os alvos de toda essa produção. Somos um lado também muito importante, porque não somos passivos, não somos meros recipientes onde os produtos da chamada indústria cultural são despejados e inteiramente absorvidos. E, ainda bem, a comunicação só acontece no encontro desses dois lados: "emissor" e "receptor". Os programas só acontecem quando nós os vemos e ouvimos; os jornais e revistas, quando os lemos.

Se é certo que a comunicação só se efetiva quando a "mensagem", aquilo que é dito, foi apropriada por quem a recebe, por nós, então se torna fundamental conhecer como funcionam os meios, para que tenhamos condições de conhecer melhor o mundo, buscando desvendar os mecanismos usados na sua edição. Só desse modo poderemos trabalhar adequadamente esses meios em nossas atividades educacionais.

Afinal, são eles a fonte primeira que educa a todos os educadores: pais, professores, agentes de comunidade, etc. Somos todos alunos: precisamos procurar entendê-los bem, saber ler criticamente as "lições" que os meios de comunicação ministram, para conseguirmos percorrer o trajeto que vai do mundo que nos entregam pronto, editado, à construção do mundo que permite a todos o pleno exercício da cidadania.

\section{POR QUE A REVISTA?}

O Curso Gestão de Processos Comunicacionais [atualmente Gestão de Comunicação], ministrado em nível de Pós-graduação [subordinado à Pró-Reitoria de Cultura e Extensão da USP a partir de agosto de 2005] pelo Departamento de Comunicações e Artes da Escola de Comunicações e Artes da Universidade de São Paulo (CCA/ECA/USP), inclui um Núcleo de "Comunicação e Educação", que tem como objetivo básico a formação de profissionais capazes de:

a) usar os recursos da comunicação/cultura no processo ensino/ aprendizagem. Tais recursos são tanto os equipamentos que eventual- 
mente a instituição educacional possua quanto os programas dos meios de comunicação que os alunos trazem consigo, pelo simples fato de, no cotidiano de suas vidas, serem também "receptores"; além da comunicação inter-pessoal, aquela que se faz utilizando-se o mais democrático de todos os equipamentos: o boca a boca.

b) saber planejar os processos de comunicação/cultura próprios do ambiente educacional. Esses processos incluem inter-relações alunos/pais/ professores/autoridades escolares/funcionários; inserção da instituição no bairro ou na cidade; utilização dos equipamentos de comunicação/ cultura que o bairro ou a cidade oferecem (museus, casas antigas, grupos musicais, grupos teatrais, etc.), entre outras.

c) desenvolver critérios e métodos para a análise das políticas e dos processos comunicacionais que se produzem através da indústria cultural, dos chamados meios massivos como o cinema, a televisão, o rádio, os jornais, as revistas. O conhecimento e a análise dessas políticas são indispensáveis para se saber os objetivos, interesses e pontos de vista a partir dos quais estão sendo construídos os programas dos meios.

O suporte da formação desse profissional é o que poderíamos chamar de uma "pedagogia dos meios", enfocada com base na ciência da comunicação, que apresenta uma natureza multidisciplinar e se constitui com base na transdisciplinaridade.

Nosso objetivo é, portanto, tentar superar o "ranço" tradicional com que os meios de comunicação costumam ser tratados na área de Educação. Esse "ranço" se expressa numa escala que vai da tentativa de subordinar os estudos dessa presença nos sistemas formais e não-formais de educação a posturas rígidas, tradicionais, incapazes de dar conta do espaço Comunicação/Educação, àquela que, muitas vezes por desconhecimento, revela um exagerado fascínio com relação aos meios e da qual resulta, inclusive, a perda da criticidade.

A decisão de criar uma publicação periódica, voltada especificamente para as inter-relações Comunicação/Cultura/Educação, resulta dessa postura e tem as seguintes premissas:

a) os meios de comunicação estão nas salas de aula, quer das escolas que possuem um aparato tecnológico de primeira linha (escolas e clientela de nível socioeconômico A), quer naquelas que podemos denominar de escolas de "terra batida e pés descalços";

b) os meios de comunicação estão presentes no cotidiano das pessoas e nelas introjetados, de tal modo que, onde houver seres humanos, os meios estarão presentes.

Isso posto, consideramos que compete ao educador conhecer os meios e saber utilizá-los a favor de seus objetivos e, para tanto, professores e educadores precisam ser informados sobre a construção e edição desse "mundo de representações". Desse modo, ao "receber" os produtos 


\section{Dez anos a serviço da construção do campo comunicação/educação • \\ Maria Aparecida Baccega}

culturais, sua percepção será diferenciada, possibilitando uma leitura mais adequada do mundo.

\section{SEÇÕES DA REVISTA}

Para atingir seus objetivos, a revista comportará as seguintes seções permanentes:

a) Editorial: onde se expressa o ponto de vista dos editores sobre os temas apresentados naquele número;

b) Apresentação: objetiva oferecer um possível roteiro de leitura;

c) Artigos Nacionais: de autoria de educadores, comunicadores e pesquisadores, deverão abordar ampla variedade de temas, relacionados ao espaço Comunicação/Educação.

d) Artigos Internacionais: aqui serão publicados estudos produzidos no exterior, de repercussão internacional. Já temos a exclusividade da tradução para a língua portuguesa dos trabalhos publicados na revista Communication Research Trends, do conceituado Centre for the Study of Communication and Culture, da Universidade Saint Louis, EUA.

e) Entrevistas: com professores, pesquisadores e profissionais que se destacam em projetos na área de interesse da revista.

f) Crítica: nesta seção serão publicadas críticas sobre a produção dos meios massivos, sobre as "mensagens" construídas, constituindo, portanto, mais um subsídio para a "leitura crítica dos meios de comunicação", conforme propõe o texto da nova LDB, já aprovado pela Câmara Federal e em tramitação no Senado.

g) Depoimentos: seção escrita por profissionais que "fazem" os meios. Nela se conta, por exemplo, como foi realizada uma determinada propaganda, como é elaborada uma novela, como se dá a produção de um programa de televisão ou de rádio, como se faz um jornal diário, ou uma revista (de notícias ou em quadrinhos, ou outras), como se produz e divulga um livro, etc.

h) Experiência: aqui serão publicados relatos de atividades no campo da Comunicação/Educação, realizadas em sala de aula ou em instituições de educação não-formal. O relato será escrito pelo próprio professor e/ou educador que fez a experiência.

i) Serviços: onde se registram eventos, cursos, lançamentos de livros e tudo o mais que possa auxiliar a formação continuada, e a especialização de comunicadores e educadores.

j) Boletim Bibliográfico: apresenta uma relação de filmes, vídeos, livros, artigos de revistas e outras produções sobre Comunicação/Educação. 
Como podemos observar, em 1994 a internet ainda não ocupava o lugar de destaque que hoje tem, conforme as várias contribuições sobre a temática que a revista vem publicando.

A Apresentação continua a "oferecer um possível roteiro de leitura”, o qual passou a ser antecedido de uma discussão acadêmica sobre alguns tópicos tratados naquele número. Os 30 artigos de Apresentação compõem com razoável clareza um pouco da história da construção desse campo, de 1994 a 2005.

Outra transformação deveu-se à solicitação de nossos leitores: o tópico Videografia desmembrou-se de Boletim Bibliográfico e ganhou uma seção própria, dada sua importância. Essa seção é de responsabilidade de Maria Ignês Carlos Magno. Incluiu-se, ainda, o tópico Serviços úteis na internet, numa tentativa de colaborar com os professores oferecendo endereços de sites, com comentários. Esse tópico tem sido de responsabilidade de Patrícia Carla dos Santos.

"Assim se passaram dez anos", diz Lupicínio Rodrigues. Atualizando, gostaríamos de encerrar afirmando que certamente os próximos dez anos se passarão com muito mais produção de conhecimento no campo Comunicação/Educação. A estrada está aberta e, hoje, nela se pode circular com razoável desenvoltura.

Resumo: Recupera a proposta editorial da revista e seus pressupostos firmados sobre o campo comunicação/educação, de 1994. Naquele momento, "Destaca que a publicação proporcionará aos leitores instrumentais para a compreensão dos mecanismos utilizados pelos meios de comunicação para a edição do mundo. Conhecimentos fundamentais a serem tratados em sala de aula, pois colaboram para a formação do receptor crítico, permitindo-lhe o exercício da cidadania".

Palavras-chave: revista, comunicação/educação, gestão, cidadania.
Abstract: The publishing proposal of this journal is presented along with its statements on the communication/education field. It is highlighted the fact that the publishing will provide the readers with instruments for a better comprehension of the means of communication on world editing. Basic knowledgements dealed in class, as they contribute on a critic receptor formation, allowing one to exercise citizenship.

Keywords: journal, communication/ educacion, management, citizenship. 